\title{
Fluctuation of the Plasma TRH Level in Normal Subjects in a 4-Hour Observation Period
}

\author{
Mizuo AZUKIZAWA, Terunori Mitsuma ${ }^{1}$, Masahiro OTA ${ }^{2}$, \\ Tetsuro MIKI, Kiyoshi ICHIHARA2, Minoru KAWASHIMA², \\ KIYOSHI MIYAI ${ }^{2}$ AND YUICHI KUMAHARA \\ Department of Medicine and Geriatrics, and Central Laboratory for \\ Clinical Investigation, ${ }^{2}$ Osaka University Hospital, Fukushima-ku, \\ Osaka 553, and First Department of Internal Medicine, Nagoya \\ University Hospital ${ }^{1}$, Showa-ku, Nagoya 466, Japan
}

\begin{abstract}
Radioimmunoassayable TRH and TSH were measured in plasma samples taken at $5 \mathrm{~min}$ intervals for $4 \mathrm{hr}(2100-0200 \mathrm{hr})$ from 4 normal male subjects. Three subjects showed a TSH surge at $2135 \mathrm{hr}, 2455 \mathrm{hr}$ and $0150 \mathrm{hr}$, respectively. The mean plasma TRH level of the 4 subjects was $10.3-11.7 \mathrm{pg} / \mathrm{ml}$. Plasma TRH showed random fluctuation, which did not coincide with the nocturnal increase in plasma TSH.
\end{abstract}

Pituitary TSH secretion is mainly controlled by two factors: negative feedback by thyroid hormones and neural control by TRH from the hypothalamus. Since the development of a highly sensitive radioimmunoassay for hTSH has made it possible to measure the basal level of serum TSH, a diurnal variation in serum TSH has been demonstrated in normal subjects (Nicoloff et al., 1970; Patel et al., 1972; Weeke, 1973; Azukizawa et al., 1976). However, the role and mechanism of the diurnal change in the serum TSH concentration are still unknown. We found that there was no correlation between the total thyroid hormone levels and TSH levels in samples taken at 20-min intervals (Azukizawa et al., 1976). Recently Weeke and Gundersen observed that the diurnal rhythm of serum free triiodothyronine and serum TSH levels were synchronous with low levels in the daytime and high levels at night (Weeke and Gundersen, 1978). But the role of thyroid hormone levels in inducing diurnal

\footnotetext{
Received December 26, 1979.
}

change in the serum TSH levels is intriguing because a diurnal change of TSH was also fouud in hypothyroid patients (Weeke and Laurberg, 1976). Some investigators have proposed that the TSH rhythm is maintained by the circadian rhythmicity of plasma cortisol (Nicoloff et al., 1970), but this now seems unlikely because diurnal variation in the plasma TSH level was observed in adrenalectomized rats (Fukuda et al., 1975). Thus, it seems likely that the rhythm of TSH secretion is directly controlled by the central venous system. The present study was conducted to investigate the secretory change in plasma TRH levels in relation to the TSH rhythm.

\section{Materials and Methods}

Four healthy male volunteers, aged 27-35 years, participated in this study. The subjects lay supine throughout the period of the blood sampling. Samples were taken at 5-min intervals through a venous catheter, at $2100-0100 \mathrm{hr}$ from two subjects (A and B) and at $2200-0200 \mathrm{hr}$ from the other two subjects (C and D). Of each blood sample, $3 \mathrm{ml}$ was immediately mixed with $30 \mu \mathrm{l}$ of a solution of $1.5 \mathrm{mg}$ of 8 - 
hydroxy quinoline sulfate and $10 \mathrm{mg}$ of Tween 20 (Katayama Chemical Co., Japan) to prevent destruction of TRH and the mixtures were centrifuged at $10,000 \mathrm{~g}$ in a Microfuge (Beckman) for $2 \mathrm{~min}$. The supernatant plasma was rapidly frozen in dry ice and was stored until the time of extraction of TRH.

Another $2 \mathrm{~m} l$ of each blood sample was allowed to clot in a glas s tube to obtain a serum sample for measuring TSH. These serum samples were also frozen at $-20^{\circ} \mathrm{C}$ until the time of assay.

TRH was extracted from plasma samples with methanol and measured by a double-antibody radioimmunoassay as previously reported (Mitsuma et al., 1976). TRH samples from one subject were all assayed in the same assay run. The intra-assay coefficient of variation of the method, including the extraction procedure, was approximately $7 \%$ and inter-assay variation was $9.8 \%$. TSH levels in serum samples were measured by the highly-sensitive radioimmunoassay described by Pekary et al. (1975).

\section{Results}

The plasma TRH and serum TSH levels in samples taken at $5 \mathrm{~min}$ intervals are shown in Table 1. The mean plasma TRH levels were $11.7 \pm 2.9 \mathrm{pg} / \mathrm{ml} \quad($ Mean $\pm \mathrm{SE}, \mathrm{N}=49)$ for subject $\mathrm{A}, 10.3 \pm 2.9 \mathrm{pg} / \mathrm{m} l$ for subject $\mathrm{B}, 10.3 \pm 2.8 \mathrm{pg} / \mathrm{m} l$ for subject $\mathrm{C}$, and 11.1 $\pm 3.1 \mathrm{pg} / \mathrm{m} l$ for subject $D$. Nocturnal rise in the serum TSH level was seen with a peak TSH level at $2455 \mathrm{hr}$ in subject $\mathrm{A}$, at $2135 \mathrm{hr}$ in subject $\mathrm{B}$ and at $0150 \mathrm{hr}$ in subject C. Subject D showed no nocturnal rise in TSH level during the 4-hr observation period. The plasma TRH levels in all 4 subjects showed random fluctuations. The magnitudes of these fluctuation from the basal levels were 7 to $10 \mathrm{pg} / \mathrm{m} l$, which are equivalent to 50 to 100 percent of the basal values. The frequency and duration of the increases in plasma TRH differed in different individuals as shown in Fig. 1. The episodic rises in plasma TRH did not coincide with the TSH surge.

\section{Discussion}

The present study showed an episodic
Table 1. Mean plasma TRH levels in normal subjects

\begin{tabular}{ccccc}
\hline Subjects & $\begin{array}{c}\text { Age } \\
(\mathrm{yr})\end{array}$ & Sex & $\begin{array}{c}\text { Time of sampling } \\
(\mathrm{hr})\end{array}$ & $\begin{array}{c}\mathrm{TRH}^{*} \\
(\mathrm{pg} / \mathrm{m} l)\end{array}$ \\
\hline A & 28 & M & $2100-0100$ & $11.7 \pm 2.9$ \\
B & 28 & M & $2100-0100$ & $10.3 \pm 2.9$ \\
C & 35 & M & $2200-0200$ & $10.2 \pm 2.8$ \\
D & 27 & M & $2200-0200$ & $11.1 \pm 3.1$ \\
\hline
\end{tabular}

* Mean $\pm \mathrm{SE}(\mathrm{N}=49)$.

pattern of fluctuation in plasma TRH levels in normal subjects. This is the first time that such changes in the hypothalamic hormone in peripheral blood have been observed. Since in studies on the secretory patterns of hormones, samples should be taken at shorter intervals than the halftime of disappearance of the hormones from the blood, sampling at intervals of 15-20 min has been used to examine episodic secretions of ACTH, GH, TSH and other hormones. We chose a sampling interval of $5 \mathrm{~min}$, because this is about the half-time of disappearance of TRH from the blood reported by two groups (Bassiri and Utiger, 1973; Morley et al., 1979). In this study, episodic rises in the plasma TRH level were seen in all four subjects examined. These episodic rises were much greater than the intra-assay variation of the radioimmunoassay, which was 7 percent including variation during extration of TRH from the plasma. The basal level of plasma TRH differed from subject to subject. This difference was not attributable to inter-assay variation of TRH radioimmunoassay because all the samples from four subjects were measured in the same assay run. One of the authors also reported that plasma TRH concentrations were distributed in the range from less than $5 \mathrm{pg} / \mathrm{m} l$ to $60 \mathrm{pg} / \mathrm{m} l$ in norml subjects (Mitsuma et al., 1976). The amplitudes of the fluctuations of plasma TRH from the basal level were similar to those of TSH.

No relation was found between the episodic rises in plasma TRH and the 


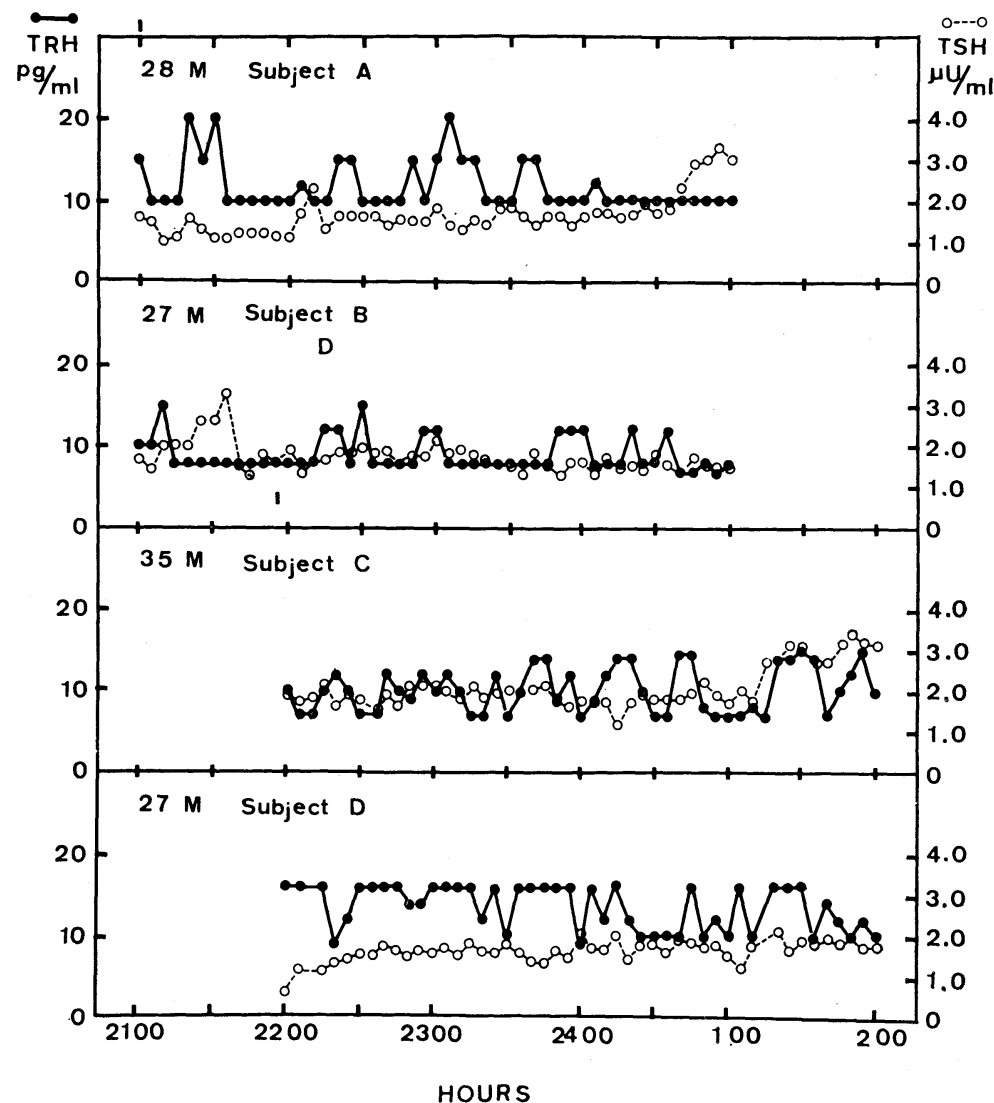

Fig. 1. Individual patterns of TRH (closed circle) and TSH (open circle) concentrations of plasma samples taken every $5 \mathrm{~min}$ for $4 \mathrm{hr}$ from 4 male subjects. nocturnal rise of serum TSH. One may speculate that the levels of hypothalamic hormones in the peripheral venous blood do not necessarily reflect the rates of secretion of hormones into the hypophyseal portal vein. The contributory effect of extrahypothalamic TRH (Jackson and Reichlin, 1974) on the peripheral blood levels of immunoreactive TRH remains unknown. However, the pulsatile release of gonadotropin-releasing hormone has been demonstrated in the pituitary stalk portal blood of rhesus monkeys (Camel et al., 1976), though the hormone levels in samples from pituitary portal blood and peripheral blood were not compared directly. Another possibility is that the frequency and magnitude of TRH release may play an important role in the diurnal variation in TSH secretion. Unfortunately this possibility could not be tested, because the blood samples required for assay of plasma TRH were so large that sampling could not be continued for $24 \mathrm{hr}$.

\section{Acknowledgements}

The authors gratefully acknowledge the hTSH RIA kit provided by the hormone distribution program of the National Pituitary Agency, U.S.A. We are also grateful to Dr. and Mrs. Akira Ichihara for correcting the English and Miss Kazue Kawabata for typing the manuscript. 


\section{References}

Azukizawa, M., A. E. Pekary, J. M. Hershman and D. C. Parker (1976). J. Clin. Endocrinol. Metab. 43, 533.

Bassiri, R. M. and R. D. Utiger (1973). J. Clin. Invest. 52, 1616.

Carmel, P. W., S. Araki and M. Ferin (1976). Endocrinology 99, 243.

Fukuda, H., M. A. Greer, L. Roberts, C. F. Allen, V. Critchlow and M. Wilson (1975). Ibid. 97, 1424.

Jackson, I. M. D. and S. Reichlin (1974). Ibid. 95, 854.
Mitsuma, T., U. Hirooka and N. Nihei (1976). Acta Endocrinol. (Kbh.) 83, 225.

Morley, J. E., T. J. Garvin, A. E. Pekary, R. D. Utiger, M. G. Nair, C. M. Baugh and J. M. Hershman (1979). J. Clin. Endocrinol. Metab. 48, 377.

Nicoloff, J. T., D. A. Fisher and M. D. Appleman Jr. (1970). J. Clin. Invest. 49, 1922.

Patel, Y. C., F. P. Alford and H. G. Burger (1972). Clin. Sci. 43, 71.

Pekary, A. E., J. M. Hershman and A. F. Parlow (1975). J. Clin. Endocrinol. Metab. 41, 676.

Weeke, J. (1973). Scand. J. Clin. Lab. Invest. 31, 337.

Weeke, J. and P. Laurberg (1976). J. Clin. Endocrinol. Metab. 43, 32.

Weeke, J. and H. J. G. Gundersen (1978). Acta Endocrinol. (Kbh.) 89, 59. 